\title{
Optimasi Jaringan Sensor Nirkabel Menggunakan Algoritma Two Sub-Swarms PSO Diskrit
}

\author{
Danang Triantoro Murdiansyah \\ Fakultas Informatika, Universitas Telkom \\ Jalan Telekomunikasi, Bandung, Indonesia
}

danangtri@telkomuniversity.ac.id

\begin{abstract}
In this paper, an algorithm based on PSO (Particle Swarm Optimization) is proposed, namely Discrete Two Sub-Swarms PSO or Discrete TSS PSO, to solve energy consumption problem in wireless sensor network. Long transmission distances between wireless sensors and base station in wireless sensor network can drain the energy of wireless sensors fast, and reduce the lifetime of the wireless sensors. To solve that problem, clustering method is chosen. By clustering a wireless sensor network into a number of wireless sensor clusters, the long distances problem for data transfer can be solved and the energy needed by wireless sensors is greatly reduced. In clustering process, a number of wireless sensors are selected to be cluster heads. Simulations show that Discrete TSS PSO algorithm can achieve good solutions fast and produces efficiency in transmission distance up to $95.36 \%$ from transmission distance that acquired by direct transmission. The performance of Discrete TSS PSO is also compared with the previous work that using GA (Genetic Algorithm) [1].
\end{abstract}

Keywords: Wireless sensor network, clustering, cluster head, discrete PSO, energy efficiency

\section{Abstrak}

Pada paper ini diusulkan sebuah algortima berbasis PSO, yaitu Two Sub-Swarms PSO Diskrit atau disingkat dengan TSS PSO Diskrit, untuk memecahkan masalah konsumsi energi pada jaringan sensor nirkabel. Jarak yang jauh antara sensor nirkabel dan stasiun utama pada jaringan sensor nirkabel dapat menyebabkan energi pada sensor nirkabel cepat habis dan menurunkan umur pakai dari sensor nirkabel tersebut. Untuk memecahkan masalah konsumsi energi tersebut, metode klasterisasi dipilih. Dengan melakukan klasterisasi pada jaringan sensor nirkabel menjadi sejumlah klaster sensor nirkabel, masalah jarak yang jauh untuk transfer data dapat diatasi dan energi yang dibutuhkan oleh sensor nirkabel jauh berkurang. Pada proses klasterisasi akan dipilih sejumlah sensor nirkabel untuk menjadi sensor kepala atau disebut juga dengan cluster head. Simulasi menunjukan bahwa algoritma TSS PSO Diskrit dapat mencapai solusi yang baik dengan cepat dan menghasilkan efisiensi jarak transmisi sampai $95.36 \%$ dari transmisi jarak yang ditempuh dengan cara transmisi langsung. Performa algoritma TSS PSO Diskrit ini juga dibandingkan dengan penelitian sebelumnya yang menggunakan AG (Algoritma Genetika) [1].

Kata Kunci: Jaringan sensor nirkabel, klasterisasi, sensor kepala, PSO diskrit, efisiensi energi 


\section{PENDAhULUAN}

ARINGAN sensor nirkabel sudah banyak digunakan dalam berbagai bidang, misalnya untuk keperluan rumah tangga, militer, dan lingkungan. Sensor nirkabel memiliki keterbatasan dalam hal kemampuan komputasi, transfer data, kapasitas penyimpanan data, dan energi. Dengan melihat keterbatasan tersebut, sensor nirkabel memiliki permasalahan yang harus diselesaikan, diantaranya adalah efisiensi, performa, dan umur dari sensor nirkabel tersebut.

Pada penelitian ini, kasus jaringan sensor nirkabel yang akan diatasi adalah jaringan sensor nirkabel dengan jumlah sensor nirkabel yang banyak dan ditempatkan pada lokasi tertentu. Semua data yang didapatkan oleh sensor nirkabel akan ditransfer menuju stasiun utama atau disebut juga dengan sink [1]. Peran stasiun utama adalah sebagai pengumpul data. Semakin jauh posisi sensor nirkabel dangan stasiun utama, maka semakin banyak pula energi yang dibutuhkan sensor nirkabel untuk mentransmisikan data ke stasiun utama.

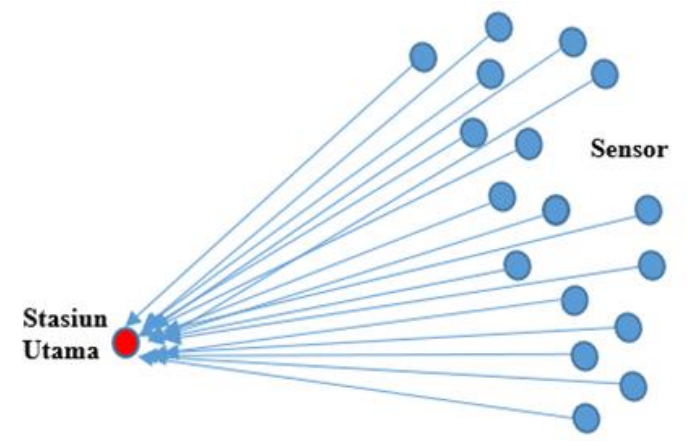

Gambar 1. Transmisi sensor nirkabel menggunakan metode transmisi langsung

Salah satu metode transmisi data dari sensor nirkabel ke stasiun utama adalah metode transmisi langsung (direct transmission), yaitu setiap sensor nirkabel mentransmisikan data yang telah didapat langsung menuju stasiun utama. Kelemahan metode ini adalah banyak menghabiskan energi sensor nirkabel karena jarak transmisi yang jauh. Adapun metode lain, yaitu dengan membentuk klaster. Dengan membentuk klaster, jaringan sensor nirkabel dipartisi menjadi sejumlah kluster sensor nirkabel. Setiap klaster memiliki sensor kepala, atau disebut juga cluster head, yang berfungsi sebagai pengumpul data dari sensor yang ada pada klaster sensor kepala tersebut berada. Setelah sensor kepala menerima data dari sensor yang bukan sensor kepala (disebut juga dengan sensor reguler), sensor kepala akan mengirimkan data ke stasiun utama.

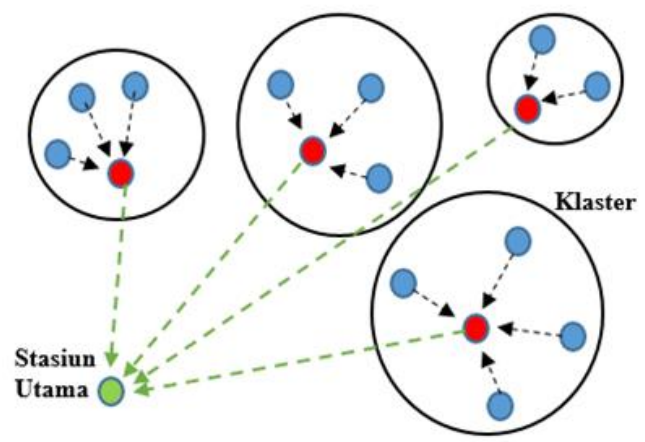

Gambar 2. Transmisi sensor nirkabel menggunakan metode klasterisasi 
Pada penelitian ini, metode yang digunakan adalah metode klasterisasi, karena dengan menggunakan metode klasterisasi, mayoritas sensor hanya mengirimkan data pada sensor kepala yang dekat, sehingga energi yang dibutuhkan jauh berkurang dari pada metode transmisi langsung. Kemudian, pada penelitian ini sensor nirkabel diasumsikan tidak bergerak atau statis, dan sensor nirkabel ditempatkan pada tempat tertentu yang diperlukan dan aman. Mayoritas sensor nirkabel jauh dari stasiun utama. Setiap sensor nirkabel memiliki kemampuan untuk menjadi sensor kepala.

Permasalahan optimasi jaringan sensor nirkabel telah banyak dikaji. Optimasi pada jaringan sensor nirkabel dapat dilakukan dengan berbagai cara, diantaranya dengan melakukan penentuan posisi sensor nirkabel, penentuan energi yang optimal untuk sensor nirkabel, penentuan konfigurasi sensor nirkabel, dan penentuan sensor kepala pada jaringan sensor nirkabel [2]. Untuk optimasi yang dilakukan pada penelitian ini, yaitu penentuan jumlah sensor kepala dan lokasinya pada jaringan sensor nirkabel, merupakan masalah yang tidak mudah diselesaikan. Penentuan jumlah sensor kepala dan lokasinya, serta menggunakan metode klasterisasi pada jaringan sensor nirkabel untuk meminimasi total jarak dari jarak seluruh sensor nirkabel ke stasiun utama, merupakan masalah yang termasuk NP-hard [3].

Pada penelitian ini digunakan algoritma berbasis PSO (Particle Swarm Optimization), yaitu algoritma Two Sub-Swarms PSO Diskrit atau disingkat TSS PSO Diskrit. Alasan pemilihan algoritma berbasis PSO adalah karena PSO merupakan algoritma yang sederhana, efektif, dan dapat diadaptasikan untuk berbagai macam permasalahan, termasuk optimasi kombinatorik. Algoritma TSS PSO Diskrit sendiri merupakan algoritma modifikasi dari algoritma TSS PSO [4] yang sudah ada, sehingga cocok digunakan untuk kasus diskrit yang ada pada penelitian ini. Performa algoritma TSS PSO Diskrit ini, dibandingkan dengan penelitian sebelumnya yang menggunakan AG (Algoritma Genetika) [1] dari sisi nilai fitness, jarak transmisi, jumlah sensor kepala yang digunakan, serta skalabilitas algoritma.

\section{PENELITIAN SEBELUMNYA}

Pada penelitian sebelumnya, permasalahan penentuan sensor kepala pada jaringan sensor nirkabel telah berhasil dipecahkan dengan menggunakan AG (Algoritma Genetika) [1]. Pada penelitian tersebut, nilai dari gen pada kromosom AG adalah bernilai 0 atau 1. Jika bernilai 1, maka sensor yang berasosiasi dengan gen tersebut akan menjadi sensor kepala (cluster head), dan jika bernilai 0 , maka sensor yang berasosiasi dengan gen tersebut akan menjadi sensor reguler. Metode yang digunakan pada penelitian ini adalah metode klasterisasi. AG mencapai performa terbaik dengan mencapai efisiensi jarak transmisi yang harus ditempuh sebesar $82.20 \%$.

Guru dkk [5] melakukan penelitian dengan menggunakan 4 varian algoritma PSO. Varian PSO tersebut adalah PSO - TVIW (Time Varying Inertia Weight), PSO - TVAC (Time Varying Acceleration Constants), Hieratchical PSO - TVAC (Time Varying Acceleration Constants), dan PSO - SSM (Supervisor Student Mode). Pada PSO - TVIW, bobot inersia $w$ berubah pada setiap iterasinya, yaitu mengalami penurunan nilai secara linier. Pada PSO - TVIW, konstanta $c_{1}$ dan $c_{2}$ nilainya berubah secara bervariasi pada setiap iterasinya. Sedangkan bobot inersia w bernilai konstan. Pada HPSO - TVAC, vektor kecepatan dirubah saat pencarian solusi mengalami kebuntuan, perubahan vektor kecepatannya tidak dipengaruhi kecepatan yang dicapai pada iterasi sebelumnya. Pada PSO - SSM, metode yang digunakan adalah metode klasterisasi. Sensor yang berada pada suatu klaster dan memiliki posisi paling dekat dengan stasiun utama, maka sensor tersebut akan menjadi sensor kepala (cluster head).

Cao dkk [6] melakukan penelitian dengan menggunakan multi level sensor kepala. Metode yang digunakannya berbasis graf, yaitu menggunakan pohon merentang minimum pada graf berbobot yang merupakan model dari jaringan sensor nirkabel. Dengan menggunakan metode tersebut akan dicari jalur terbaik dari sensor reguler ke sensor kepala. Konsumsi energi juga termasuk dalam faktor yang diperhitungkan. Pemilihan sensor kepala dilakukan berdasarkan energi yang tersedia pada sensor dan jarak antar sensor.

Pada penelitian yang lainnya, Heinzelman dkk [7] mengusulkan algoritma klasterisasi yang bernama LEACH (Low Energy Adaptiv Clustering Hierarchy). Algoritma LEACH memilih sensor kepala (cluster head) berdasarkan model probabilitas. Beberapa sensor dipilih secara acak sebagai sensor kepala. Sensor kepala memiliki beban kerja yang lebih berat sehingga lebih banyak membutuhkan energi dari pada sensor reguler. Untuk menjaga kestabilan jaringan, peran sensor kepala dirotasi untuk setiap periode atau ronde. 


\section{ALGORITMA PSO}

Pada bagian ini dibahas tentang Algoritma PSO (Particle Swarm Optmization) standar dan Algoritma Diskrit TSS PSO yang diusulkan untuk menyelesaikan permasalahan pemilihan sensor kepala pada jaringan sensor nirkabel.

\section{A. Algoritma PSO}

Pada algoritma PSO, suatu solusi direpresentasikan oleh partikel dalam swarm (sekelompok partikel) yang bergerak dalam ruang berdimensi $D$ dengan vektor posisi $x_{i}=\left(x^{k}{ }_{i l}, x^{k}{ }_{i 2,}, \ldots, x_{i D}^{k}\right)$, di mana $k$ menunjukan iterasi. Pada setiap iterasi, partikel memperbaharui kecepatannya, yaitu $v_{i}^{k}$, berdasarkan posisi terbaik yang dicapai pada iterasinya saat itu, yaitu $p^{k}$, dan berdasarkan posisi terbaik yang dicapai oleh swarm / seluruh partikel, yaitu $p_{g}$. Fungsi dari kecepatan dan posisi yang digunakan adalah sebagai berikut.

$$
\begin{gathered}
v^{k+1}{ }_{i j}=w \cdot v^{k}{ }_{i j}+c_{1} \cdot r_{1} \cdot\left(p^{k}{ }_{i j}-x^{k}{ }_{i j}\right)+c_{2} \cdot r_{2} \cdot\left(p^{k}{ }_{g j}-x^{k}{ }_{i j}\right) \\
x^{k+1}{ }_{i j}=x^{k}{ }_{i j}+v^{k}{ }_{i j}
\end{gathered}
$$

Pada fungsi di atas, $w$ adalah faktor inersia, $c_{1}$ dan $c_{2}$ adalah faktor belajar, $r_{1}$ dan $r_{2}$ adalah varibel acak. Nilai dari $w$ akan menentukan kemampuan partikel dalam mengeksplorasi ruang solusi [8]. Pada setiap iterasinya, semakin besar nilai $w$, maka partikel akan semakin memiliki kecenderungan untuk mengeksplorasi daerah yang lebih luas dalam ruang solusi. Hal tersebut juga membuat partikel memiliki kemampuan pencarian global yang semakin baik. Sedangkan nilai $w$ yang semakin kecil akan membuat partikel terbatas kemampuan eksplorasinya pada pencarian lokal. Nilai dari $c_{1}$ dan $c_{2}$ akan menentukan karakteristik konvergensi dari algoritma [8]. Semakin besar nilai $c_{1}$ akan membuat eksplorasi dari partikel terbatas pada daerah lokal dari solusi terbaik yang dicapai sebelumnya. Sedangkan semakin besar nilai $c_{2}$, pada setiap iterasinya.akan membuat eksplorasi partikel mendekati daerah solusi global yang ditemukan. Kemudian nilai dari $r_{1}$ dan $r_{2}$ akan menentukan arah dari pencarian [8].

\section{B. Algoritma PSO yang Diusulkan}

Untuk menyelesaikan permasalahan pemilihan sensor kepala pada jaringan sensor nirkabel, algoritma yang berbasis PSO (Particle Swarm Optimization), yaitu Two Sub-Swarms PSO Diskrit atau disingkat TSS PSO Diskrit, diusulkan. Algoritma TSS PSO Diskrit ini merupakan algoritma modifikasi dari algoritma TSS PSO [4] yang sudah ada, sehingga cocok digunakan untuk kasus diskrit yang ada pada penelitian ini. Algoritma TSS PSO sendiri memiliki performa lebih baik dari algoritma PSO yang biasa [4].

Pada algoritma TSS PSO Diskrit, partikel akan dibagi ke dalam 2 klaster dengan ukuran yang sama. Pada klaster partikel yang ke-1, diimplementasikan model algoritma PSO seperti biasa, yaitu menggunakan fungsi (1) dan (2). Sedangkan pada klaster partikel yang ke-2, diimplementasikan model yang hanya memperhitungkan bagian kognisi saja [9], yaitu menggunakan fungsi (2) dan (3).

$$
v^{k+1}{ }_{i j}=w \cdot v_{i j}^{k}+c_{1} \cdot r_{1} \cdot\left(p^{k}{ }_{i j}-x_{i j}^{k}\right)
$$

Selain itu, pada algoritma yang diusulkan ini, digunakan persamaan linier (4) [10] untuk menentukan sensor mana saja yang akan menjadi sensor kepala dan sensor mana yang akan menjadi sensor reguler. Digunakan $x_{\text {binary }}^{k}{ }_{i j}$, yaitu vektor posisi yang elemennya bernilai 0 atau 1. Nilai dimensi dari $x_{b i n a r y}{ }_{i j}$ adalah sebanyak sensor yang digunakan. Jika elemen ke-j dari $x_{b i n a r y}{ }_{i j}$ bernilai 1, maka sensor ke-j yang berasosiasi dengan elemen ke-j tersebut merupakan sensor kepala. Sebaliknya, jika bernilai 0, maka sensor tersebut merupakan sensor reguler. Berikut ini adalah persamaan linier [8] yang digunakan

$$
L\left(x_{i j}\right)=\left(x_{i j}-R \min \right) /(\operatorname{Rmax}-R \min )
$$




$$
\text { binary }_{i j}^{k}=\left\{\begin{array}{c}
1, \text { random }() \leq L(x i j) \\
0, \text { lainnya }
\end{array}\right.
$$

Rentang nilai dari fungsi linier $L\left(x_{i j}\right)$ adalah $(0,1)$. Fungsi random() pada persamaan (5) memliki distribusi normal. Rentang nilai dari fungsi random() adalah [0, 1]. Sedangkan Rmin dan Rmax merupakan konstanta dengan nilai tertentu yang telah ditentukan sebelumnya dengan $R \min <R \max$.

Untuk langkah pada algoritma TSS PSO Diskrit adalah sebagai berikut.

1) Inisialisasi jumlah partikel dari setiap sub swarm / klaster partikel, jumlah iterasi maksimum, bobot inersia w, posisi awal dan kecepatan awal dari partikel, serta Rmin dan Rmax.

2) Untuk sub swarm ke-1, hitung kecepatan yang baru berdasarkan persamaan (1) dan posisi yang baru berdasarkan persamaan (2). Untuk sub swarm ke-2, hitung kecepatan yang baru berdasarkan persamaan (3) dan posisi yang baru berdasarkan persamaan (2).

3) Pada masing masing sub swarm, hitung posisi yang baru untuk vektor posisi yang bernilai diskrit, yaitu binary $_{i j}{ }_{i j}$, dengan menggunakan persamaan linier (4) dan persamaan (5).

4) Pada masing - masing sub swarm, perbaharui posisi terbaik pada iterasi saat itu, yaitu perbaharui $p^{k}$, dan juga posisi terbaik dari seluruh partikel, yaitu perbaharui $p_{g}$.

5) Pertukarkan partikel antar sub swarm. Partikel pada sub swarm ke-2 yang lebih baik dari partikel pada sub swarm ke-1, akan menggantikan partikel pada sub swarm ke-1 tersebut. Begitu juga dengan partikel pada sub swarm ke-1 yang digantikan oleh partikel pada sub swarm ke-2, akan menggantikan partikel sub swarm ke-2 pada sub swarm ke-2.

6) Jika iterasi telah mencapai yang ditentukan, maka algoritma TSS PSO Diskrit berhenti.

Dengan menggunkan algoritma yang merupakan modifikasi dari algoritma TSS PSO ini, kemungkinan terjebak pada optimum lokal akan lebih kecil dibandingkan dengan PSO standar. Pada algoritma TSS PSO, keberagaman partikel akan terjaga dengan baik, dan konvergensi prematur yang disebabkan oleh ditemukannya solusi ekstrim dapat terhindari [4].

\section{Evaluasi Fungsi Fitness}

Pada permasalah pemilihan sensor kepala pada jaringan sensor nirkabel ini, faktor yang akan dioptimasi adalah jarak transmisi dan jumlah sensor kepala serta lokasinya. Semakin kecil jarak transmisi yang ditempuh, maka akan semakin sedikit energi yang dibutuhkan sensor. Demikian juga dengan semakin sedikitnya sensor kepala, maka energy yang dibutuhkan akan semakin sedikit. Hal tersebut karena sensor kepala membutuhkan lebih banyak energi dibandingkan dengan sensor reguler. Untuk mengoptimasi jarak transmisi dan jumlah sensor kepala serta lokasinya, fungsi fitness (6) berikut ini digunakan untuk mengevaluasi setiap partikel PSO. Fungsi fitness ini diambil dari penelitian sebelumnya yang menggunakan Algoritma Genetika [1].

$$
\text { Fitness }=w e *\left(D-\text { distance }_{i}\right)+(1-w e) *\left(N-H_{i}\right)
$$

Pada fungsi di atas, wi adalah parameter yang akan menentukan faktor mana yang akan lebih diperhitungkan pada saat evaluasi fungsi fitness. Rentang nilai wi adalah [0,1]. Jika wi bernilai 1, maka optimasi pada jaringan sensor nirkabel dilakukan dengan hanya memperhitungkan jarak transmisi. Sedangkan jika nilai wi bernilai 0 , maka optimasi pada jaringan nirkabel dilakukan dengan hanya memperhitungkan jumlah sensor kepala. Parameter $D$ adalah total jarak transmisi dari semua sensor nirkabel ke stasiun utama. Dengan kata lain, $D$ adalah total jarak transmisi saat menggunakan perhitungan biasa, yaitu transmisi langsung, tidak ada yang berperan sebagai sensor kepala. Sedangkan distance $_{i}$ adalah jarak transmisi dari seluruh sensor reguler ke sensor kepala, ditambah dengan jarak transmisi dari seluruh sensor kepala ke stasiun utama. Jadi distance $e_{i}$ adalah total jarak transmisi yang dicapai oleh algoritma TSS PSO Diskrit. Parameter $N$ adalah jumlah dari seluruh sensor yang digunakan, sedangkan $H_{i}$ adalah jumlah sensor kepala. Dengan melihat fungsi fitness di atas, semakin 
kecil distance $_{i}$ atau semakin kecil $H_{i}$, maka partikel akan memiliki nilai fitness yang semakin baik / semakin besar.

\section{HASIL EKSPERIMEN}

Pada ekperimen ini, digunakan area dengan luas $200 \times 200$ satuan persegi. Posisi yang dapat diisi sensor adalah mulai dari koordinat (0, 0) sampai $(200,200)$. Jumlah partikel PSO yang digunakan adalah 20 partikel, sedangkan $w i=0.8, c_{1}=c_{2}=5, R \min =-50$, dan $R \max =50$. Nilai dari parameter wi, Rmin, dan Rmax diambil berdasarkan rekomendasi pada [10]. Menurut [10], dengan nilai tersebut, dapat dicapai hasil optimasi yang terbaik. Untuk parameter lainnya, digunakan 800 iterasi, 100 sensor nirkabel, dan $w=0.8$. Nilai parameter tersebut diambil berdasarkan penelitian sebelumnya yang telah dilakukan dengan menggunakan AG [1], sehingga hasil eksperimen ini dapat dibandingkan dengan hasil eksperimen yang menggunakan AG tersebut. Pada eksperimen ini, skenario yang digunakan juga disesuaikan dengan penelitian sebelumnya. Pada eksperimen ini disimulasikan perubahan nilai maksimum fitness, jarak minimum transmisi, dan jumlah sensor kepala yang digunakan. Selain itu, diuji juga skalabilitas dari algoritma TSS PSO Diskrit ini.

\section{A. Perubahan Nilai Fitness, Jarak, dan Jumlah Sensor Kepala Terhadap Iterasi}

Pada bagian ini, melalui Gambar 1, 2, dan 3, ditunjukan bagaimana perubahan nilai fitness maksimum, jarak minimum, dan jumlah sensor kepala. Semua perubahan tersebut ditinjau per iterasi.

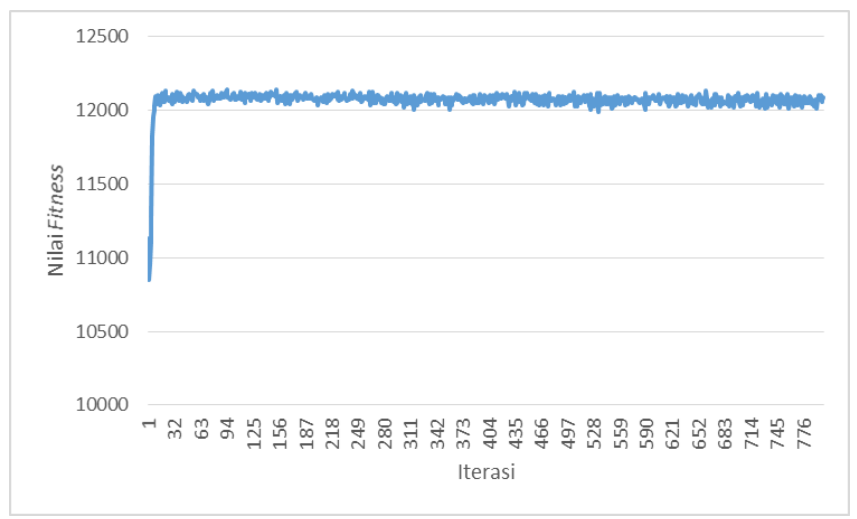

Gambar 3. Perubahan nilai maksimum fitness terhadap iterasi 


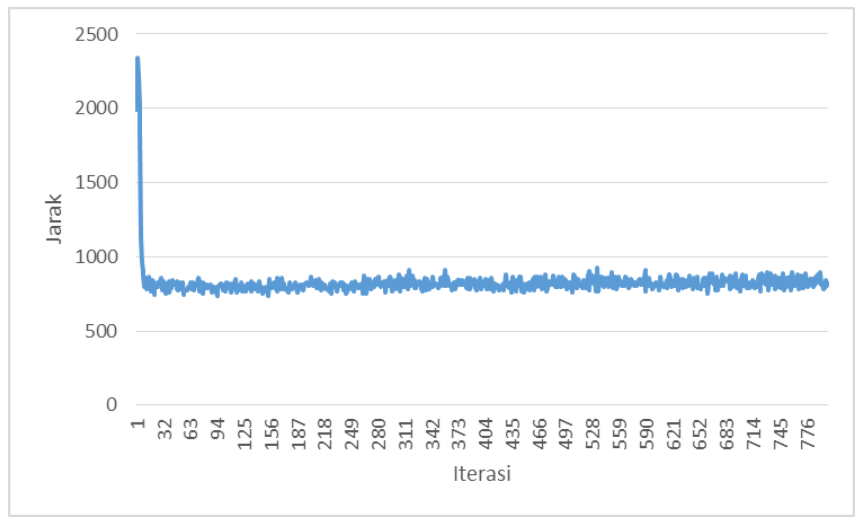

Gambar 4. Perubahan jarak minimum terhadap iterasi

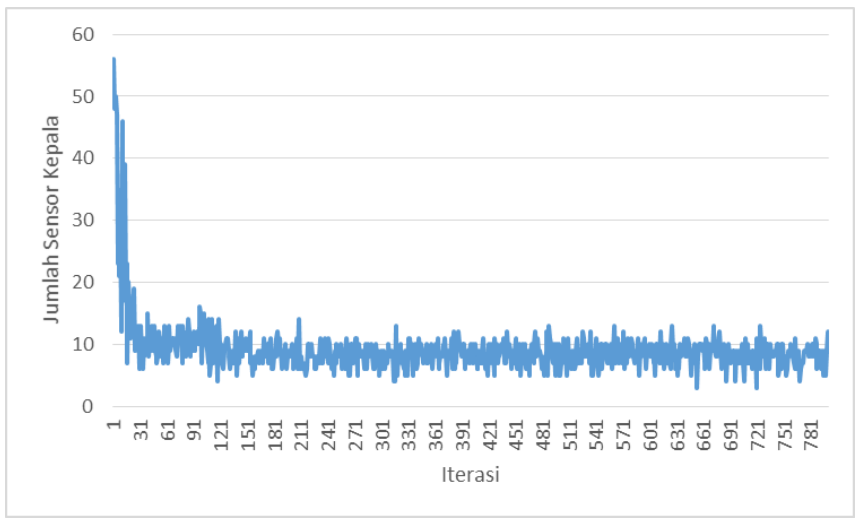

Gambar 5. Perubahan jumlah sensor kepala terhadap iterasi

Hasil ekperimen menunjukan bahwa algoritma TSS PSO Diskrit efektif dan efisien dalam menyelesaikan permasalahan pemilihan sensor kepala pada jaringan sensor nirkabel. Algoritma TSS PSO Diskrit dapat dengan cepat mendekati solusi yang baik. Selain itu, jika dibandingkan dengan penelitian sebelumnya yang menggunakan Algoritma Genetika [1], TSS PSO Diskrit dapat menyelesaikan permasalahan tersebut dengan lebih baik. Algoritma TSS PSO Diskrit dapat menghasilkan hasil yang berada disekitar solusi yang baik hanya dalam 55 iterasi. Ini lebih baik dari pada yang telah dicapai Algoritma Genetika. Algoritma Genetika mencapai solusi yang baik setelah 120 generasi [1]. Sebagai data perbandingan Gambar 6 dan 7 [1] merupakan hasil yang dihasilkan oleh AG [1]. 


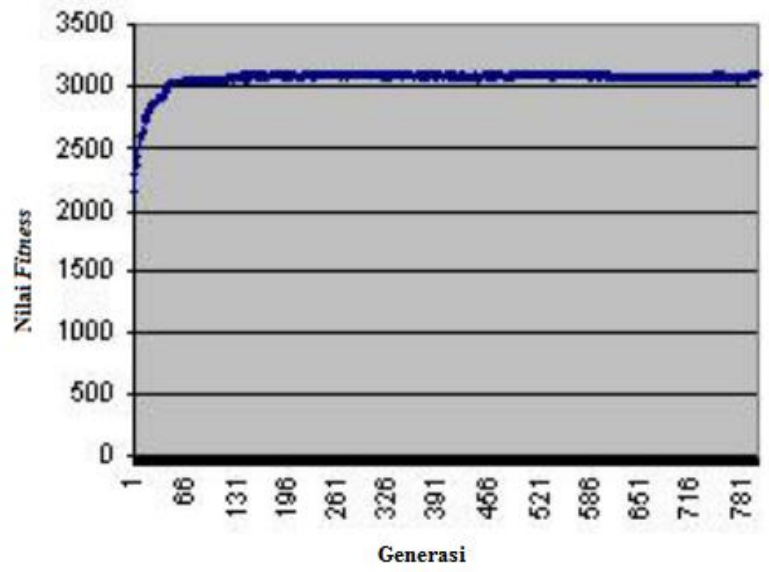

Gambar 6. Perubahan nilai maksimum fitness terhadap iterasi yang dihasilkan AG [1]

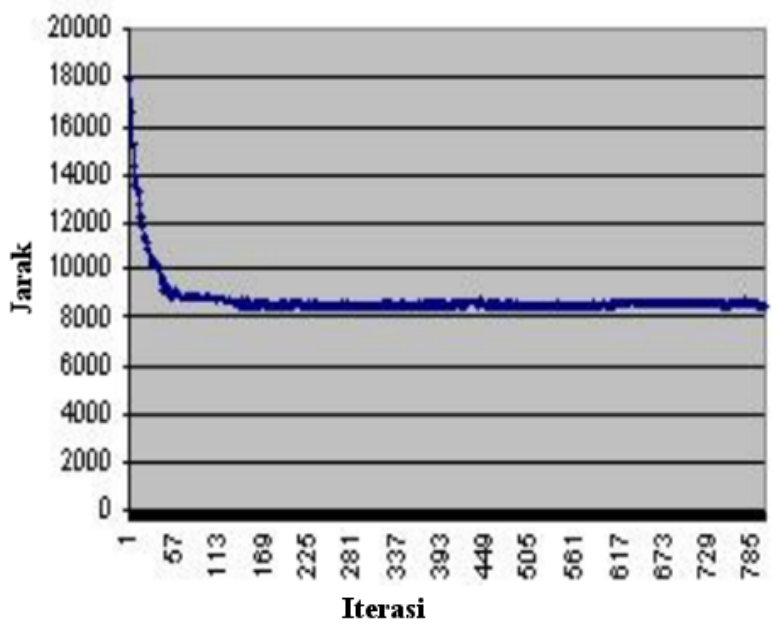

Gambar 7. Perubahan jarak minimum terhadap iterasi yang dihasilkan AG [1]

\section{B. Skalabilitas}

Dalam dunia nyata, spesifikasi kebutuhan sensor nirkabel sangatlah beragam, salah satunya adalah beragamnya jumlah sensor nirkabel yang dibutuhkan. Tidak jarang dalam suatu kasus, ratusan sensor nirkabel dibutuhkan [1]. Oleh kerena itu, sangatlah penting untuk menguji skalabilitas algoritma TSS PSO Diskrit. Dalam pengujian skalabilitas ini, dilihat perubahan performa dari algoritma TSS PSO Diskrit jika jumlah sensor yang digunakan terus meningkat. Dalam pengujian ini, disimulasikan kasus dengan beragam jumlah sensor nirkabel, yaitu 100, 200, dan 400. Tabel 1 di bawah merupakan hasil pengujian yang dilakukan dari algoritma TSS PSO Diskrit. 
TABEL 1

TABEL HASIL PENGUJIAN TSS PSO DISKRIT

\begin{tabular}{|l|l|l|l|}
\hline $\begin{array}{l}\text { Jumlah } \\
\text { Sensor }\end{array}$ & $\begin{array}{l}\text { Jumlah } \\
\text { Partikel } \\
\text { PSO }\end{array}$ & $\begin{array}{l}\text { Jumlah } \\
\text { Sensor } \\
\text { Kepala }\end{array}$ & $\begin{array}{l}\text { Penurunan } \\
\text { Jarak }\end{array}$ \\
\hline 100 & 20 & $10.00 \%$ & $95.36 \%$ \\
\hline 200 & 30 & $11.70 \%$ & $93.17 \%$ \\
\hline 400 & 40 & $14.20 \%$ & $87.90 \%$ \\
\hline
\end{tabular}

Sebagai perbandingannya, terdapat Tabel 2 di bawah, yaitu tabel yang merupakan hasil penelitian sebelumnya yang menggunakan Algoritma Genetika [1].

TABEL 2

TABEL HASIL PENGUJIAN AG [1]

\begin{tabular}{|l|l|l|l|}
\hline $\begin{array}{l}\text { Jumlah } \\
\text { Sensor }\end{array}$ & $\begin{array}{l}\text { Ukuran } \\
\text { Populasi } \\
\text { AG }\end{array}$ & $\begin{array}{l}\text { Jumlah } \\
\text { Sensor } \\
\text { Kepala }\end{array}$ & $\begin{array}{l}\text { Penurunan } \\
\text { Jarak }\end{array}$ \\
\hline 100 & 80 & $10.00 \%$ & $76.85 \%$ \\
\hline 200 & 160 & $10.00 \%$ & $81.20 \%$ \\
\hline 400 & 300 & $11.20 \%$ & $82.20 \%$ \\
\hline
\end{tabular}

Jumlah partikel PSO ataupun ukuran populasi AG harus ditingkatkan sejalan dengan semakin banyaknya jumlah sensor yang digunakan. Hal tersebut dilakukan agar performa algoritma tetap terjaga. Pada TSS PSO Diskrit, jumlah partikel PSO yang digunakan adalah berkisar 20 s.d. 40 partikel. Rentang jumlah tersebut merupakan rentang jumlah yang disimpulkan dari [11]. Menurut [11], sebaiknya jumlah partikel tidak lebih dari 50 partikel.

Dari Tabel 1, dapat disimpulkan bahwa TSS PSO Diskrit dapat dengan baik menyelesaikan permasalahan pemilihan sensor kepala pada jaringan sensor nirkabel. TSS PSO Diskrit dapat melakukan efisiensi dari sisi jarak transmisi yang harus dilalui sampai $95.36 \%$ dari total jarak transmisi langsung. Dari sisi ini, TSS PSO Diskrit lebih baik dari AG [1]. AG mencapai efisiensi jarak transmisi terbaik sampai 82.20\%. Angka tersebut lebih kecil dari yang dicapai TSS PSO Diskrit.

Dari Tabel 1 dan Tabel 2, dapat disimpulkan bahwa semakin banyak jumlah sensor yang digunakan, maka semakin banyak jumlah sensor kepala yang dibutuhkan. Hal ini disebabkan karena semakin banyak sensor, maka area penyebaran sensor pun akan semakin meluas, sehingga dibutukan sensor kepala lebih banyak untuk mengakomodasi sensor reguler yang berada pada berbagai sudut area.

\section{KESIMPULAN}

Pada penelitian ini, diusulkan algoritma berbasis PSO, yaitu TSS PSO Diskrit, untuk menyelesaikan permasalah pemilihan sensor kepala pada jaringan sensor nirkabel melalui klasterisasi. Dengan tepatnya pemilihan sensor kepala, maka jarak transmisi akan berkurang dan energi yang dibutuhkan untuk transmisi akan lebih sedikit. Algoritma TSS PSO Diskrit ini merupakan modifikasi dari TSS PSO [4] yang sudah ada sehingga cocok digunakan untuk kasus diskrit. Algoritma TSS PSO Diskrit memilih sensor kepala berdasarkan probabilitas yang perhitungannya melibatkan fungsi linier. Setelah sensor kepala dipilih, nilai fitness dari setiap partikel PSO akan dihitung dan pemilihan sensor kepala akan diperbaharui kembali berdasarkan perhitungan nilai fitness tersebut. Algoritma TSS PSO Diskrit dapat memilih dan menentukan jumlah sensor kepala dengan baik. Simulasi menunjukan bahwa algoritma TSS PSO Diskrit dapat dengan cepat mendapatkan solusi yang baik dan dapat mencapai efisiensi jarak transmisi sampai 95.36\%. Dari sisi efisiensi jarak transmisi yang 
DANANG TRIANTORO MURDIANSYAH

dicapai, algoritma TSS PSO Diskrit lebih baik jika dibandingkan Algoritma Genetika [1] yang digunakan pada penelitian sebelumnya. Algoritma Genetika mencapai efisiensi jarak transmisi sampai $82.20 \%$.

\section{REFERENSI}

[1] S. Jin, M. Zhou, and A. S. Wu, "Sensor network optimization using a genetic algorithm," Proc. 7th World Multiconference, pp. 1-6, 2003

[2] R. V. Kulkarni and G. K. Venayagamoorthy, "Particle swarm optimization in wireless-sensor networks: A brief survey," IEEE Trans. Syst. Man Cybern. Part C Appl. Rev., vol. 41, no. 2, pp. 262-267, 2011.

[3] P. M. Pardalos, F. Rendl, and H. Wolkowicz, "The Quadratic Assignment Problem : A Survey and Recent Developments," in In Proceedings of the DIMACS Workshop on Quadratic Assignment Problems, volume 16 of DIMACS Series in Discrete Mathematics and Theoretical Computer Science, 1994, vol. 00, pp. 1-42.

[4] Z. Yu, W. Wu and L. Wu, "An Improved Particle Swarm Optimization Algorithm Based on Two Sub-swarms", Advances in Intelligent and Soft Computing, pp. 443-448, 2012.

[5] S. M. Guru, S. K. Halgamuge, and S. Fernando, "Particle Swarm Optimisers for Cluster formation in Wireless Sensor Networks," in Proceedings of the 2005 International Conference on Intelligent Sensors, Sensor Networks and Information Processing Conference, 2005, 2005, pp. 319-324.

[6] X. Cao, H. Zhang, J. Shi, and G. Cui, "Cluster heads election analysis for multi-hop wireless sensor networks based on weighted graph and particle swarm optimization," in Proceedings - 4th International Conference on Natural Computation, ICNC 2008, 2008, vol. 7, pp. 599-603.

[7] W. B. Heinzelman, a. P. Chandrakasan, and H. Balakrishnan, "An application-specific protocol architecture for wireless microsensor networks," IEEE Trans. Wirel. Commun., vol. 1, no. 4, pp. 660-670, 2002.

[8] O. Ilaya, C. Bil, and M. Evans, "A particle swarm optimisation approach to graph permutations," in Conference Proceedings of 2007 Information, Decision and Control, IDC, 2007, pp. 366-371.

[9] J. Kennedy, "Small worlds and mega-minds: Effects of neighborhood topology on particle swarm performance," in Proceedings of the 1999 Congress on Evolutionary Computation, CEC 1999, 1999, vol. 3, pp. 1931-1938.

[10] L. Wang, X. Wang, J. Fu and L. Zhen, "A Novel Probability Binary Particle Swarm Optimization Algorithm and Its Application", JSW, vol. 3, no. 9, 2008.

[11] L. Zhang, H. Yu, and S. Hu, "Optimal choice of parameters for particle swarm optimization,” J. Zhejiang Univ. Sci., vol. 6A, no. 6, pp. 528-534, 2005. 